\title{
Organisation of breeding under difficult framework conditions - the case of smallholder pig breeding in mountainous areas in Northwest Vietnam
}

\author{
Regina Roessler', Pera Herold ${ }^{1}, 2$, Helmut Momm and Anne Valle Zárate \\ 'Institute of Animal Production in the Tropics and Subtropics, Universität Hohenheim, Stuttgart-Hohenheim, Germany, \\ ${ }^{2}$ Landesanstalt für Geoinformation und Landentwicklung, Kornwestheim, Germany
}

\begin{abstract}
The concentration process in the international livestock breeding industry has led to an increasing competitive pressure for existing regional livestock breeding institutions. This represents an almost insuperable barrier for the competitive organisation of livestock breeding under difficult framework conditions, particularly in developing countries. The present study aimed at identifying possibilities how to develop the organisation of livestock breeding under difficult framework conditions, taking smallholder pig breeding in mountainous areas in Northwest Vietnam as example. Information was collected from group discussions with small-scale pig producers in Son La province and interviews in various private and public breeding institutions across northern Vietnam, complemented by information from documents. Results show that smallholder pig breeding is influenced by numerous external private and public factors, respectively institutions. These include small private boar keepers and medium-sized commercial pig farms at village and district level, but also globally acting private breeding companies and relevant legislations. Considering the identified institutional framework situation of smallholder pig breeding at village level and the generally positive attitude of smallholders towards cooperative structures, the establishment of boar keeper cooperatives is recommended as a first step in the development of a competitive breeding organisation at village level. Altogether, the current situation of smallholder pig breeding at village level makes the establishment of village breeding programmes reasonable, given a more rigorous implementation of supportive legislations that promote and recognise the self-determination of the proposed cooperative breeding organisations.
\end{abstract}

Keywords: organisation of breeding, smallholder pig breeding, village breeding programmes, northern Vietnam

\section{Introduction}

In recent years, the concentration process in the international livestock breeding industry, particularly in the poultry, pig and cattle breeding sectors, has resulted in few globally acting breeding companies. These multinational companies represent an economic entity across different countries, including developing ones. Trade liberalisation facilitates an increasing growth in international trade of livestock products, and emerging technologies such as genomic selection will further accelerate concentration in the livestock breeding 
industries. This concentration will exacerbate genetic monoculture, leading to a loss in livestock genetic diversity (Gura 2008). Above developments have already led to an increasing competitive pressure for regional livestock breeder cooperatives in developed countries, and represent an almost insuperable barrier for the organisation of livestock breeding under difficult framework conditions, particularly in developing countries like Vietnam. In Vietnam, recent developments such as the WTO accession, increased foreign investment, changes in consumption and wealth distribution patterns, trends toward large commercial production systems and increasing importance of export markets considerably affect the pig production sector. These developments also bear the risk of an exclusion of small-scale pig producers from benefits achieved through the economic growth of the pig production sector. Village breeding programmes incorporating local pig breeds are currently developed for improving smallholder pig production in the mountainous province Son La (Herold et al. 2010, Roessler et al. 2009). The long-term success of such programmes depends not only on their technological excellence, but also on the organisational feasibility of breeding measures under given framework conditions. The present study therefore aimed at identifying possibilities how to develop the organisation of livestock breeding under difficult framework conditions, taking smallholder pig breeding at village level in mountainous areas in Northwest Vietnam as example.

\section{Material and methods}

\section{Study area, selected villages and institutions}

This study is part of a long-term research project of the Thai-Vietnamese-German collaborative research programme "Sustainable land use and rural development in mountainous areas in Northeast Asia" (`The Uplands Program`) of the University Hohenheim. This project targets at the development and implementation of village breeding programmes in Son La province in the mountainous areas in northwestern Vietnam since more than 10 years, using an integrated approach. Main research focus was therefore in that province.

Table 1

Private and public institutions approached in the survey

\begin{tabular}{lclc}
\hline Private institutions & Number & Public institutions & Number \\
\hline Farmer groups & 26 & Central and local ministries & 3 \\
Village boar keepers & 8 & Public companies & 4 \\
Commercial farms & 5 & Public service providers & 5 \\
Pig traders (local markets) & 2 & National research institutes/ universities & 2 \\
Joint venture (with foreign company) & 1 & Other institutions (Rural Development & 2 \\
& & Centre, Farmer Association Son La) & \\
Foreign-invested company & 1 & & \\
Producer cooperative & 1 & & \\
\hline
\end{tabular}

Eight villages were selected, differing in distance from the provincial or district capital (5 villages close to and 3 villages far from the capital), ethnic affiliation (6 Black Thai, 2 Hmong villages) and pig production type (6 villages with market-oriented, 2 villages with subsistence-oriented production). In total, 26 farmer groups with on average five smallholder pig producers each were approached in the survey. Pig producers were randomly selected 
from a list of all pig producers keeping sows that had been provided by the village head of each village. In addition, 20 persons belonging to 18 private institutions and 31 persons from 16 public institutions (Table 1) were approached in personal interviews. Institutions were located in a total of nine northern provinces (Son La, Hai Duong, Thai Binh, Quang Ninh, Ninh Binh, Ha Tay, Hung Yen, Hai Phong and Hanoi).

\section{Methods}

The evaluation of institutions involved in the organisation of pig breeding in the investigated area was based on the classification of livestock breeding institutions suggested by Herold et al. (2012). The authors differentiate between institutions in the private and public area. The private area includes cooperative businesses of livestock keepers and commercial breeding businesses with private investors who are usually not livestock keepers (e.g. multinational breeding companies). Breeding in the public area takes place in breeding institutions (e.g. state-owned breeding stations). In addition, institutions related to breeding are defined, in both, the private and public area. In the private area, these include e.g. organisations responsible for performance recording and downstream tiers like dairy factories and slaughterhouses, farms, markets and business networks. In the public area, institutions related to breeding comprise breeding regulations (e.g. breeding law) and support institutions (e.g. research institutes, breeding administration).

The present study further used the situational approach (e.g. Vahs 2009). In this approach, it is assumed that the structure of an organisation (in the present study: the organisation of smallholder pig breeding at village level) is dependent on certain factors, respectively institutions, of a specific situation (e.g. markets, competitors, legislation). The aim of the pragmatic type of the situational approach is to identify how to best "fit" the structures of the respective (breeding) organisation to its specific situation.

Data collection was realised from April-December 2006 and September-December 2007, using question guidelines. Key issues addressed in the group discussions included a general description of the organisation of pig breeding at village level and an identification and characterisation of forms of farmer organisation with activities related to pig production, as well as an identification of influencing factors and linkages to other institutions involved in the organisation of pig breeding. Purposive sampling of further institutions involved in pig breeding organisation was realised by snow ball technique (Johnson 2005). Informal interviews aimed at gaining an insight into the structure of the respective institution, animal numbers and flows, information flows and decision making, as well as major external factors (legal environment, policies, financial support, competition, networks and partnerships). A further step of the research included a desk study comprising a screening of legal documents (laws, governmental and ministerial decisions), reports and project descriptions as well as information from the internet to back and complete the information gathered in the surveys.

Information obtained in interviews and group discussions were recorded in field notes. Structured protocols of interviews and group discussions were entered in Microsoft Word and Microsoft Excel (Microsoft Corporation, Redmond, WA, USA), respectively. Data was analysed mainly qualitatively, matching the categories of the question guideline: Primary organisation, farmer organisations, framework conditions (e.g. supply of breeding animals, technologies 
and trainings, legal regulations, market conditions) and linkages to other institutions. The qualitative analysis was complemented by a descriptive, quantitative analysis of group discussion data, using within and across village comparison. The use of different methods for data collection and analysis provided the opportunity for cross-validating results.

\section{Results}

Pig breeding institutions at village level

Village household farms

Pig breeding in the investigated villages in Son La province was still mainly organised on individual, small household farms with an average of 1-2 sows. Only in one investigated village, two larger household farms, each with five exotic sows and one boar, were established in recent years. Sows mostly originated from other household farms within the same village (6 villages) or from other villages, or were selected from the own herd (3 villages each). By contrast, the purchase from commercial farms or the town market was rarely reported (1 village each) (Figure 1). According to farmers, sows from the town market were considered less adapted to local conditions (climate, feeding) because they were imported from lowland areas and difficult to transport to the village or had an unclear origin (2 villages each). The supply of breeding sows tended to be insufficient and irregular; however, differences between farmers within and across villages could be observed.

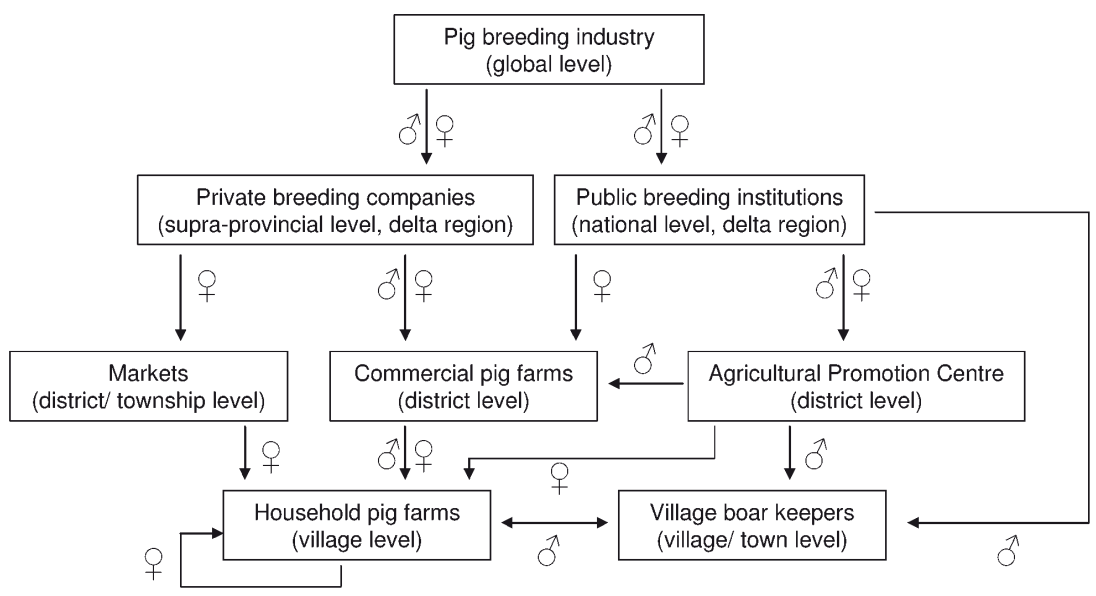

Figure 1

Extended supply channels for breeding pigs used at household farms in investigated villages

Village farmer groups

Individual farm households were formally organised in different farmer groups. These comprised common socio-political village groups of mass organisations in Vietnam like e.g. the Women's Union or the Farmers' Association (all villages), as well as agricultural extension clubs (2 villages) as a new form of a state-induced farmer organisation, and a pig production 
group established by individual farmers (1 village) (Table 2). According to farmers, these groups helped to gain access to micro-credits (either from the group or the bank). Yet, funding was generally mentioned not to be sufficient to cover farmers' needs. Groups also facilitated the exchange of experiences and information between members, either in regular meetings or on study tours to other villages, helping farmers improving their technical skills. Farmers also gained access to new technologies including new pig breeds, and benefited from trainings on the use of such new technologies. Yet, according to farmers, training courses were not taking place regularly (3 villages), practical advice and financial support to apply new technologies was lacking (2 villages) or topics were not relevant or applicable to the respective production system (1 village each). Further constraints comprised a limited number of participants and a restricted access to trainings (1 village each). The pig production group also served as a platform for the exchange of breeding sows between group members.

Table 2

Types and functions of farmer organisations in investigated villages

\begin{tabular}{|c|c|}
\hline Types of farmer organisations & Functions of farmer organisations \\
\hline Common political village groups (8 villages) & $\begin{array}{l}\text { Access to micro-credits } \\
\text { Exchange of experiences and information }\end{array}$ \\
\hline Village agricultural extension clubs (2 villages) & $\begin{array}{l}\text { Improvement of technical skills by regular meetings } \\
\text { and through study tours } \\
\text { Training on new technologies/breeding for club } \\
\text { head and members } \\
\text { Access to new technologies and micro-credits }\end{array}$ \\
\hline Pig production groups (1 village) & $\begin{array}{l}\text { Exchange of experiences and information } \\
\text { Source of breeding animals }\end{array}$ \\
\hline
\end{tabular}

Despite the perceived limitations, farmers' attitude towards existing farmer organisations was generally positive (11 of 18 group discussions). Only in one village, the attitude was clearly negative, farmers not perceiving any advantages. In the two investigated remote villages of the ethnic minority Hmong, the opinion of farmers towards farmer organisations was heterogeneous. Main reasons against farmer groups were that the establishment and operation of such groups require considerable funds while not benefiting members ( 3 of 4 group discussions) and that farmers lacked knowledge and motivation to set-up such groups (2 of 3 group discussions).

The attitude towards cooperatives or collective farming structures among Thai farmers in villages with market-oriented pig production was also mostly positive (7 of 12 group discussions). Perceived advantages were risk sharing, labour sharing, better access to land and loans, farmer-to-farmer learning, specialisation of farmers, lower input prices e.g. for animal feed, better access to extension services and possibilities for technological transfer. In three group discussions, farmers stated that cooperatives would not help to improve their pig production. Arguments against cooperatives included lack of experiences, land, feed and labour to run intensified practices of production, and strict regulations on production and management. Farmers also feared that they would lose independency in their decisionmaking and that outputs would not be shared according to inputs. Farmers in remote Hmong villages lacked both, experiences with cooperative farming in the past and knowledge on 
new forms of cooperatives or collective farming structures that are encouraged through the Vietnamese government (Decision 166/2001/QD-TTg; Law 18/2003/QH11; DLP 2006) and hence did not express any opinion about such structures.

\section{Village boar keepers}

In all investigated villages at least one village boar was available either used for natural mating (all villages) or for artificial insemination (Al) (2 villages). In addition, pig producers in villages with market-oriented pig production regularly used boar and Al services from boar keepers of neighbouring villages or Son La town ( 5 and 2 villages, respectively). Farmers of one more remote Thai village commonly bought semen from the boar keeper in Son La town for inseminating their sows (Figure 1). By contrast, the Al services offered by commercial farms at district level were used rarely by village pig producers (1 village). Interviewed village boar keepers owned 1-3 boars, mainly from exotic breed lines (all boar keepers), but also of the local Mong Cai or Ban breed (2 boar keepers each). Exotic boars were mostly purchased from large public breeding farms in the delta region (6 of 8 village boar keepers) (Figure 1). Farmers in the Hmong villages did not have access to other mating services than from within the same village due to their remoteness.

\section{Institutional framework (situation) of pig breeding institutions at village level}

Pig breeding at village level was influenced by various institutions from town/district level up to global level, albeit at varying extent. A summary of the institutional framework (situation) of smallholder pig breeding at village level is presented in Table 3.

Table 3

Institutional framework (situation) of smallholder pig breeding at village level

\begin{tabular}{lll}
\hline Institution & Area & Level \\
\hline Markets & Private & District/township \\
Commercial pig farms & Private & District \\
Support services & Public, private & District, provincial \\
Breeding institutions and companies/industry & Public, private & National, global \\
Legislation, policies, administrations & Public & Provincial, national, global \\
\hline
\end{tabular}

\section{Markets}

In the two districts under study, two market places for Mong Cai breeding sows existed. At these market places, approximately 40-60 sows were sold per month. Pigs had been collected from household farms in the delta region and were mainly sold to household farms in and close to Son La town. No Ban or exotic pigs were marketed for breeding.

\section{Commercial pig farms}

In recent years, some private, small- to medium-size commercial pig farms have been developing in Son La province (interviews: Sub-Department of Animal Health [SDAH] of Son La township and Farmer Association of Son La province, 2006). The exact number of such farms in Son La province could, however, not be identified; yet the number can be assumed 
small as more than $90 \%$ of the provincial pig population were still kept at small household farms (DARD 1999). By contrast, this type of farms has been gaining increasing importance in other parts of the country, particularly in the Red River Delta, where they already represented $36 \%$ (Hai Duong province) and $60 \%$ of all farm types (Ha Tay province) (Lapar et al. 2003).

In total, five commercial pig farms have been visited in Son La township and Mai Son district. The herd size on investigated farms varied from 18-350 exotic sows and annual production figures ranged between 240 and more than 1000 slaughter pigs. The sows used at commercial farms mainly originated from both, large public institutions and private companies in the delta region, while boars were mostly purchased from the large private Thai company Charoen Pokphand (CP) located close to Hanoi (3 farms); only one farm purchased boars from the district Agricultural Promotion Centre (Figure 1). Boars were mostly for internal use, only the largest farm offered Al service to other commercial and small household farms. Besides private boar keepers and commercial farms, neither provincial Al stations nor public breeding farms existed in Son La province, since former provincial breeding farms have been dissolved (interview: SDAH of Son La Township 2006). Local authorities planned to build a district pig breeding farm in Song Ma district, but its realisation seemed doubtful due to lack of funding. In addition, a former breeding centre in Mai Son district was said to be reorganised into a semi-governmental farm (interviews: DARD 2006; Agricultural Extension Station (AES) of Song Ma district 2006).

\section{Support services}

In Son La township, demonstration models have been established in 2007 by the Agricultural Extension Station (AES) to improve smallholder pig breeding at small household farms. Participating farmers received subsidies for the purchase of breeding females ( $60 \%$ for the first $30 \mathrm{~kg}$ of gilts) and for feed costs ( $40 \%$ of feed costs for $100 \mathrm{~kg}$ of feed per sow). According to the implementing body, the success of the model seemed, however, questionable as model farmers have faced problems with the disease management, exotic sows tending to be more susceptible to prevailing diseases. Another research project targeting at developing smallholder pig breeding was implemented by the Agricultural Promotion Centre (APC) of Mai Son district. This project covered 30 households in four villages in different communes, each household farm keeping 3-4 exotic sows that originated from the nucleus managed by the APC. Again, the continuation of the project seemed unlikely due to unavailable further funding and the failure of most household farms to keep exotic sows (disease management, high input costs).

Training courses for farmers in the investigated villages were organised by the district AES (4 villages), the provincial Agricultural Extension Centre, the district People Committee or the Sub-Department of Animal Health (1 village each). Other institutions supporting smallholder pig breeding in the investigated villages included private animal health workers (3 villages).

\section{Breeding institutions and companies/industry}

At national level, there existed several public breeding institutions including breeding companies, research institutes and universities. The most important national research institute foranimal sciences in Vietnam was the formerNational Institute of Animal Husbandry (NIAH), now National Institute of Animal Sciences (NIAS). It had two pig research centres where the national 
pork leanisation programme was implemented using imported pig lines in crossbreeding schemes to genetically improve breeding pigs. It aimed at developing a pyramidal breeding system (NIAH 2003). One of the most important public pig production institutions was the Vietnam National Livestock Corporation (VINALIVESCO). It had 7 pig production units across the whole country providing parent stock sows and breeding boars to public and private institutions, including smallholder household farms. To meet the increasing demand for pork, VINALIVESCO planned cooperation with groups and cooperatives of local farmers in the Red River Delta to extend the production of commercial stock (interviews: VINALIVESCO 2006; National Centre for Pig Breeding and Al 2006 and Northern Pig Breeding Company 2006). From the in total 15 breeding institutions at national level, the public pig breeding system further spread to breeding farms and Al stations at provincial level. In the whole country, in 2005, there were 51 farms under provincial management (interviews: Department of Livestock Production, Ministry of Agriculture and Rural Development 2007), and the total number of registered boar breeding units for Al amounted to more than 450 in 2006, with around 4200 boars producing nearly 5.7 million doses of semen per year (DLP 2006).

In addition to public breeding companies, there existed private farms with grand parent stock ( 65 farms) and parent stock sows (195 farms). The largest farms were mainly located in southern Vietnam and the delta region in northern Vietnam. Twelve companies were foreign invested (interviews: Department of Livestock Production, Ministry of Agriculture and Rural Development 2007), the largest company being the Thai Charoen Pokphand (CP) Group with 50000 sows and 600 boars, including 3600 great grand parent stock. Other foreign invested companies in southern Vietnam included the San Miguel Limited Company, the France Hybrids Company of the Glon Group (DLP 2006) and a franchise for JSR Genetics stock (UK), established with the largest Korean pig breeding company Darby Genetics (DLP 2006, JSR 2006). The Duc Viet Limited Company was a private German Vietnamese joint stock company, located in the northern province Hung Yen.

It is expected that Vietnam's WTO accession in 2007 will have considerable effects on the country's economy in general and its pig breeding sector in particular. According to experts on national level, public breeding institutions will have to improve breed quality and standards and increase capacities. Price stability has to be achieved and environmental issues (e.g. water pollution) have to find special attention in future livestock planning. This will probably further widen the gap between small farmers' needs and preferences for local breeds and the objectives of public breeding institutions.

Legislation, policies, administrations

Both, national and provincial policies clearly concentrated on the transformation of pig production from small-scaled and dispersed forms to concentrated commercial ones to meet the local and export demand for pork. At national level, they targeted at reducing the number of pigs kept traditionally from $70 \%$ in 2005 to $60 \%$ in 2010 and changing the pig breed structure by increasing the proportion of exotic sows from $10 \%$ in 2005 to $19 \%$ in 2010 and $27 \%$ in 2015 , while reducing the number of local sows from $13 \%$ to $11 \%$. The importation of improved breeds and the establishment of breeding farms with exotic sows and institutions producing breeding pigs for exports were encouraged and preferential investment policies were provided (e.g. Decision 17/2006/QD-TTg; Decision 166/2001/QD-TTg; Decree 14/CP; DLP 
2006, MARD 2000). Also poor farmers who invest in exotic and new breeds were supported by the government (Joint Circular 101/2001). Foreign investment into the livestock sector was encouraged, the government offering foreign investors a lower corporate tax of $10 \%$ for livestock investment projects (compared with a $28 \%$ corporate tax rate for other kinds of investments) and unlimited leasing periods for rural land dedicated to livestock production (Bundesagentur für Außenwirtschaft 2006, Foreign Affairs and International Trade Canada 2006). Equally, the Agriculture and Rural Development Plan of the Son La province (DARD 2005), mainly targeted to increase the number of pigs from 452000 in 2004 to 584000 in 2010 to meet the high local demand for pork. The proportion of unimproved local sows in the total sow population was to be reduced from nearly $50 \%$ in 2000 to $10 \%$ in 2010 , while increasing the proportion of improved local Mong Cai sows from 50 to $70 \%$ and that of F1 sows from 0.5 to $20 \%$ in the same period (DARD 1999). To realise the above plans, the development of largescale keeping of lean meat pigs particularly in peri-urban areas, is supported by providing investors with financial advantages (Decision 257/QD-UB). Farm managers of the private commercial farms that have been visited confirmed to be exempt from land use taxes and to get compensation for land clearing ( 3 farms) and assured to get free vaccination for pigs and technical advice from the Sub-Department of Animal Health (2 farms).

Nevertheless, the use and conservation of local pig breeds was also promoted by the state (e.g. Decision 225/1999/QD-TTg; DLP 2006). Hitherto, conservation programmes have mostly been implemented in the delta region, e.g. for the I pig, the Lang Hong, the Phu Khanh and the Mong Cai. More recent policies foresee the improvement of local pig breeds and the development of brands and geographical indications in the Western Highland, East-Southern and West-Northern region. Besides the research project in which the present study has been conducted, several other small research projects have been carried out targeting at the in situ conservation of local breeds: the Muong Khuong and Mong Cai in Lao Cai province, the Tap Na in Cao Bang province, the Lung Pu in Ha Giang province (interviews: MARD 2005, DLP 2006).

In addition, legal documents have been issued in the last decades that generally regulated the pig breeding and production, directed state policies on livestock breeds and defined responsibilities for the state management of livestock breeds, prescribed conservation, research and selection, and defined a wide range of terminologies in animal breeding (Ordinance 16/2004/PL-UBTVQH11, Decree 14/CP and Joint Circular 04/2004/TTLT/BTCBNNTPNT). According to Government Decree 66/2003/ND-CP, the Ministry of Agriculture and Rural Development (MARD) is responsible for the governmental management of agriculture, rural development and public services. The Ministry's tasks are performed by a number of institutions and functional units under the direction of MARD. The functional units are classified into professional, research, service delivery and production units. The most important professional unit within MARD with regard to livestock production was the Department of Livestock Production (DLP).

\section{Discussion}

In Vietnam, the use of local sows such as the Mong Cai, Muong Khuong and Lang breed is still more common than the use of sows of exotic breed lines which only represented about $10 \%$ of all sows in the country in 2005 (DLP 2006). In Son La province, about $99 \%$ of reproducing 
sows are of the Mong Cai and other local breeds (DARD 1999), and the pig production is mainly restricted to small household farms with few sows. The local Mong Cai and Ban breeds are appreciated for their feed intake spectrum and capacity as well as high disease tolerance, and the Mong Cai breed is also preferred due to its high prolificacy (Herold et al. 2010, Roessler et al. 2009, Lemke et al. 2006).

Hitherto breeding sows at these small farms are mostly selected from unimproved village herds. By contrast, the purchase of breeding stock from the market, larger private pig farms as well as public breeding institutions is limited. The same has been reported by Lemke et al. (2006). Reasons are that larger farms and public institutions exclusively keep exotic sows and that Mong Cai sows sold at the markets are considered less adapted to local conditions in the mountainous areas. Nevertheless, a small number of Mong Cai gilts are regularly transferred from the delta region and marketed in Son La town, obviously because the local production is unable to cover the local demand as provincial breeding centres that were a source for Mong Cai sows in the investigated area until 1997 (Lemke \& Valle Zárate 2008) are now absent. On the male side, small pig producers mostly used the services of private boar keepers at village and town/district level. In the past, the keeping of boars at small household farms in the investigated area has become uncommon in villages close to towns since the 1980s, being mainly limited to remote villages with no access to public Al services formerly provided by a provincial breeding centre and later by the Extension Department (Lemke \& Valle Zárate 2008). The present study shows that the public Al services are no longer in place, resulting in an increase in the number of private boar and Al service providers based at village level.

Although the multiple supply channels indirectly extend to the global pig breeding industry that dominates local markets for breeding pigs with less adapted pig breeds, smallholder farmers hardly have access to genetically superior, well-adapted local breeding stock, being beset with exotic breeding products that are distributed through demonstration models. Therefore, the establishment of village breeding programmes seems reasonable, particularly in combination with supply chain systems as suggested by Herold et al. (2010) to ensure the supply of such breeding pigs to smallholder farmers in the investigated villages.

Further considering the identified institutional framework situation of smallholder pig breeding at village level, including the topography of Northwest Vietnam, the establishment of boar keeper or breeder cooperatives is recommended. Boar keeper cooperatives are considered as pre-stage of breeder cooperatives and are mainly limited to the purchase and the targeted use of valuable sires for already existing breeds or breeds to be developed. By contrast, breeder cooperatives are involved in the whole breeding process (purchase of breeding stock, selection of sires and dams, marketing of breeding stock). These organisational forms proved to be particularly suitable for small farms (Brödermann 1897) and have been competitive for more than hundred years (e.g. Brödermann 1897, Kronacher 1923, Schweer 1979, Hodapp 1983, BESH 2009). Boar keeper and breeder cooperatives are primarily organisations based on self-help and were recommended to associate with other similar cooperatives to strengthen themselves in general and to get effective public support in particular (e.g. Fischer 1900). In Vietnam, new style cooperatives and other innovative farmer organisations have been increasingly promoted by the national government (Binh et al. 2007, Costales et al. 2005) to provide different types of services to smallholders, decrease input costs through collective purchases and respond to smallholders' needs (Binh et al. 2002, Tuy 2002). 
The already existing farmer groups in the villages could form the basis for the establishment of breeder cooperatives or associations. When establishing innovative farmer groups, however, certain difficulties that are due to the specific socio-political context in Vietnam (Schad et al. 2011) are to be avoided. These include shortcomings already in the early stages of the group formation such as non-transparent group formation and biased appointment of group members, and later the unclear allocation of responsibilities and role of group members (Schad et al. 2011), and other limitations identified in the present study. A statute that is adapted to the local conditions and that regulates the definition of breeding objectives, breeding measures (e.g. performance tests), the participation of breeder-members in breeding and organisational decisions, monitoring compliance with the rules and sanctions for rule violations can help overcome the mentioned difficulties. Also, due to farmers' limited knowledge of the new concept of cooperatives and lack of experiences and practical advice to set-up cooperatives, it is vital to support them to gain this knowledge and to provide practical support in forming cooperatives. In this context, Binh \& Thai (2002) and Thai et al. (2002) underline the importance to develop links to researchers and state organisations in order to coordinate collective actions, institutionalise and acquire legal recognition and overcome constraints such as weak technical and managerial capacities and capabilities in commercial and contractual negotiations of farmer cooperatives.

Currently, Vietnamese support services, legislation and policies principally focus on the modernisation of the pig sector and promote the establishment of large-scale commercial farms for lean meat production. On the other hand, they include relatively detailed regulations and measures for the maintenance of local pig breeds. Despite the recognition of the importance of local breeds, particularly for mountainous areas, programmes and studies to conserve local pig breeds are limited to a few breeds and regions. Drucker et al. (2006) identified a considerable number of agricultural subsidies that improve the competitiveness of exotic breeds and their crosses over local breeds and forecast that without mitigating measures local breeds will become extinct. Furthermore, neither breed improvement nor conservation programmes are uniform across the provinces (ASPS 2002). Thus, already Huyen et al. (2005) concluded that the long-term sustainability of conservation programmes for local pig breeds in Vietnam is doubtful. By combining breeding programmes with small food supply chains as suggested by Herold et al. (2010), local breeds could be effectively integrated into existing production chains and no special conservation programme would be necessary. However, such a concept will be only successful when there are local farmer cooperatives that are responsible for the management of the breeding and marketing of local breeds. Also, a more rigorous implementation of existing legal regulations and measures is necessary to promote the suggested cooperative breeding organisations, in addition to public financial support, particularly at the beginning of forming cooperatives, and a public recognition of the self-determination of cooperatives with effective controls.

\section{Acknowledgements}

The financial support of the Federal State of Baden-Württemberg and the German Research Council (DFG) are gratefully acknowledged. 


\section{References}

ASPS (2002) Livestock policy briefs for Vietnam. MARD - DANIDA: Agriculture Sector Programme Support ASPS; Agrifood Consulting International ACl, Hanoi, Vietnam

BESH (2009) Bäuerliche Erzeugergemeinschaft Schwäbisch-Hall. http://www.besh.de/ [last accessed 15.01.2009]

Binh VT, Thai BT (2002) Cooperation for a lean pig production. Participatory process of innovation creation and dissemination. In: Scaling up innovative approaches in agricultural development. Results of and lessons learned from research studies on agricultural development carried out in the Red River basin by partners of the French-Vietnamese cooperation. Agricultural Publishing House, Hanoi, Vietnam, 39

Binh VT, Thai BT, Quang HV, Moustier P (2007) The role of farmer organisations and researcher support in the inclusion of smallholders in quality pork supply chains in Vietnam. Presentation to the 106th seminar of the European Association of Agricultural Economics (EAAE) »Pro-poor development in low income countries: Food, agriculture, trade, and environment", 25-27 October 2007, Montpellier, France

Binh VT, Thai BT, Thinh NV, Casabianca F (2002) Cooperation for a lean pig production. Chronicle of "professionalisation " process. In: Scaling up innovative approaches in agricultural development. Results of and lessons learned from research studies on agricultural development carried out in the Red River basin by partners of the French-Vietnamese cooperation. Agricultural Publishing House, Hanoi, Vietnam, 40

Brödermann EA (1897) [Basics of breeding and breeding associations]. In: [Recent experiences in the field of animal breeding]. Arbeiten der Deutschen Landwirtschafts-Gesellschaft 28, 129-152 [in German]

Bundesagentur für Außenwirtschaft (2006) [Vietnam's livestock breeding sector solicits foreign invested capital. Expansion of the meat and dairy production/ German top position in equipment imports]. bfai. Servicestelle des Bundesministeriums für Wirtschaft und Technologie. https://www.bfai.de/ext/ Einzelsicht-Export/DE/Content/__SharedDocs/Links-Einzeldokumente-Datenbanken/fachdokument,te mplateld=renderPrint/ MKT20060420104725.pdf [last accessed 27.07.2007] [in German]

Costales A, Son NT, Lapar L, Tiongco M, Delgado C (2005) Smallholder contract farming of swine in Northern Viet Nam: Study design. Research report. Pro-Poor Livestock Policy Iniative. A Living from Livestock. FAO, Rome, Italy

DARD (1999) Livestock Production Development Plan in 2000-2010. Department of Agriculture and Rural Development, Son La, Vietnam [in Vietnamese]

DARD (2005) Agriculture and Rural Development Plan 2005-2010. Department of Agriculture and Rural Development, Son La, Vietnam [in Vietnamese]

DLP (2006) Livestock Production Report: Pig breeding system and quality in 2001-2005 and national directions for pig production 2006-2010. Ministry of Agriculture and Rural Development, Department of Livestock Production, Hanoi, Vietnam [in Vietnamese]

Drucker AG, Bergeron E, Lemke U, Thuy LT, Valle Zárate A (2006) Identification and quantification of subsidies relevant to the production of local and imported pig breeds in Vietnam. Trop Anim Health Prod 38, 305-322

Fischer M (1900) [Manual of livestock breeding theory]. Leipzig, Germany [in German]

Foreign Affairs and International Trade Canada (2006) The pork market in Vietnam. Agri-Food Trade Service. November 2006. Report prepared by the Business Sectors Bureau (BMM) Foreign Affairs and International Trade Canada (DFAIT) and Trade Evaluation and Analysis Division (TEAD), Agriculture and Agri-Food Canada (AAFC). Government of Canada. http://www.ats.agr.gc.ca/asean/4292_e.htm [last accessed 17.12.2008]

Gura S (2008) Industrial livestock production and its impact on smallholders in developing countries. Consultancy Report to the League for Pastoral Peoples and Endogenous Livestock Development (www. pastoralpeoples.org), Germany

Herold P, Roessler R, Valle Zárate A, Momm H (2012) Development of organisation and planning in animal breeding: I. A review on breeding organisation. Arch Tierz 55, 402-414

Herold P, Roessler R, Willam A, Momm H, Valle Zárate A (2010) Breeding and supply chain systems incorporating local pig breeds for small-scale pig producers in Northwest Vietnam. Livest Sci 129, 63-72 
Hodapp C (1983) [Design of the marketing for pig breeding associations]. Dissertation, Institute of Animal Husbandry and Animal Breeding, University Hohenheim, Stuttgart, Germany [in German]

Huyen LTT, Roessler R, Lemke U, Valle Zárate A (2005) Impact of the use of exotic compared to local pig breeds on socio-economic development and biodiversity in Vietnam. Stuttgart, Germany

Johnson, TP (2005) Snowball sampling. Encyclopedia of Biostatistics. Wiley Online Library

JSR (2006) JSR plays key role 'growing' Vietnamese market. http://www.thepigsite.com/swinenews/12841/ jsr-plays-key-role-growing-vietnamese-market [last accessed 15.11.2012]

Kronacher C (1923) [Animal breeding]. Second edition, Berlin, Gemany [in German]

Lapar ML, Binh VT, Ehui S (2003) Identifying barriers to entry to livestock input and output markets in Southeast Asia. Livestock sector report: Vietnam. FAO, Rome, Italy

Lemke U, Kaufmann B, Thuy LT, Emrich K, Valle Zárate A (2006) Evaluation of smallholder pig production systems in North Vietnam: Pig production management and pig performances. Livest Sci 105, 229-243

Lemke U, Valle Zárate A (2008) Dynamics and developmental trends of smallholder pig production systems in North Vietnam. Agric Syst 96, 207-223

MARD (2000) Agriculture and Rural Development 5-year Plan (2001-2005). Ministry of Agriculture and Rural Development (MARD) of the Socialist Republic of Vietnam. Hanoi, Vietnam

MARD (2005) The 5-year plan for the agricultural and rural development sector, period 2006-2010. Ministry of Agriculture and Rural Development (MARD) of the Socialist Republic of Vietnam. Unofficial translation by the International Support Group (ISG) secretariat of MARD.

NIAH (2003) High-tech breeding programme. News February 2003. National Institute of Animal Husbandry, Hanoi, Vietnam. http://www.cucchannuoi.gov.vn [last accessed 12.07.2006] [in Vietnamese]

Roessler R, Herold P, Willam A, Piepho HP, Thuy LT, Valle Zárate A (2009) Modelling of a recording scheme for market-oriented smallholder pig producers in Northwest Vietnam. Livest Sci 123, 241-248

Schad I, Roessler R, Neef A, Valle Zárate A, Hoffmann V (2011) Group-based learning in an authoritarian setting? Novel extension approaches in Vietnam's Northern upland. J Agric Educ Ext 17, 85-98

Schweer H (1979) [Farmer organisation for hybrid pig breeding]. Hohenheimer Arbeiten 102, Stuttgart, Germany [in German]

Thai BT, Binh VT, Thinh NV, Thanh LS (2002) Cooperation for a lean pig production. New challenges for a new cooperative in Nam Sach district. In: Scaling up innovative approaches in agricultural development. Results of and lessons learned from research studies on agricultural development carried out in the Red River basin by partners of the French-Vietnamese cooperation. Agricultural Publishing House, Hanoi, Vietnam, 41

Tuy DT (2002) Several examples of farmers' organisations. Diversifying the forms of organisation in agriculture to provide different types of services and respond to farmers' needs. In: Scaling up innovative approaches in agricultural development. Results of and lessons learned from research studies on agricultural development carried out in the Red River basin by partners of the French-Vietnamese cooperation. Agricultural Publishing House, Hanoi, Vietnam, 28

Vahs D (2009) [Organisation: a teaching and management book]. 7th ed., Stuttgart, Germany [in German]

Received 15 December 2011, accepted 25 May 2012.

Corresponding author:

Regina Roessler

email: regina.roessler@uni-hohenheim.de

Institute of Animal Production in the Tropics and Subtropics, Universität Hohenheim, Garbenstr. 17, 70599 Stuttgart-Hohenheim, Germany 